\title{
Isolation and characterization of new phenolic siderophores with antimicrobial properties from Pseudomonas sp. UIAU-6B
}

\author{
Emmanuel T. Oluwabusola ${ }^{*}$, Olusoji O. Adebisi ${ }^{2}$, Fernando Reyes ${ }^{3}$, Kojo S. Acquah ${ }^{4}$, \\ Mercedes De La Cruz ${ }^{3}$, Larry L. Mweetwa ${ }^{1}$, Joy E. Rajakulendran ${ }^{1}$, Digby F. Warner ${ }^{4}$, \\ Deng Hai ${ }^{1}$, Rainer Ebel ${ }^{1}$ and Marcel Jaspars ${ }^{*}$
}

\section{Full Research Paper}

\begin{abstract}
Address:
${ }^{1}$ Marine Biodiscovery Centre, Department of Chemistry, University of Aberdeen, Scotland, UK, ${ }^{2}$ Department of Microbiology, Faculty of Life Sciences, University of Ilorin, Kwara State, Ilorin, Nigeria, ${ }^{3}$ Fundación MEDINA, Centro de Excelencia en Investigación de Medicamentos Innovadores en Andalucía, Avenida del Conocimiento 34, Parque Tecnoloógico de Ciencias de la Salud, E-18016 Granada, Spain and ${ }^{4}$ Wellcome Centre for Infectious Diseases Research in Africa, University of Cape Town, Rondebosch, 7701, South Africa

\section{Email:}

Emmanuel T. Oluwabusola* - r01eto@abdn.ac.uk; Marcel Jaspars ${ }^{*}$ m.jaspars@abdn.ac.uk

* Corresponding author

Keywords:

Mycobacterium tuberculosis; Phenolic siderophores; pseudomonine;

Pseudomonas sp.; vancomycin-sensitive Enterococcus faecium
\end{abstract}

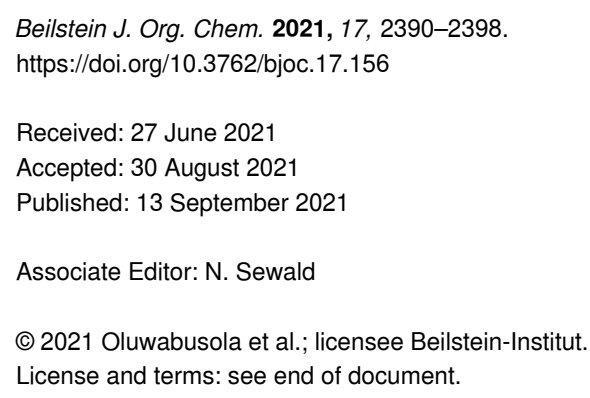

\begin{abstract}
Five new phenolic siderophores 1-5 were isolated from the organic extract of a culture broth in a modified SGG medium of Pseudomonas sp. UIAU-6B, obtained from sediments collected from the Oyun river in North Central Nigeria. The structure of the new compounds, pseudomonin A-C (1-3) and pseudomobactin A and B (4 and 5) isolated alongside two known compounds, pseudomonine (6) and salicylic acid (7), were elucidated based on high-resolution mass spectrometry, 1D and 2D NMR analyses. The absolute configuration of the threonine residue in compounds 1-5 was determined by Marfey analysis. The antimicrobial evaluation of compound 4 exhibited the most potent activity against vancomycin-sensitive Enterococcus faecium VS144754, followed by $\mathbf{3}$ and 5, with MIC values ranging from 8 to $32 \mu \mathrm{g} / \mathrm{mL}$. Compounds $\mathbf{2}$ and $\mathbf{3}$ exhibited moderate activity against Mycobacterium tuberculosis $\mathrm{H} 37 \mathrm{Rv}$, with MIC values of 7.8 and $15.6 \mu \mathrm{g} / \mathrm{mL}$, respectively. Plausible biosynthetic hypotheses toward the new compounds 1-5 were proposed.
\end{abstract}

\section{Introduction}

The introduction of antimicrobial drugs in the mid-20th century has had an unprecedented positive impact on human health, but the current threat of multiple drug resistance may well roll back all these past achievements [1]. One way out of this is an extensive search for novel bioactive natural products from microbial sources [2,3]. 
There is focus on the genus Pseudomonas for scientific research due to its widespread distribution in water, soil, and extreme habitats, including the exceptional ability to colonize the rhizosphere of host plants, serving as a microbial biocontrol [4,5]. This genus, belonging to the Gram-negative proteobacteria is diverse in nature and possesses unique environmental adaptability which shows in their versatile metabolism [6-8]. They are prolific producers of natural products with broad-spectrum biological functions which include antifungal [9-11] and antibacterial activities [12-14]. Natural product scaffolds isolated from species of this genus have contributed immensely as leads to drug discovery and development [15]. For instance, clofazimine [16], the antimycobacterial agent used for the treatment of leprosy and inflammation was inspired by the natural product phenazine $[17,18]$. Also, pseudomononic acid (mupirocin) isolated from Pseudomonas fluorescens by Fuller and co-workers in 1971 was discovered to possess novel antibacterial activities against 310 clinical isolates of Staphylococcus aureus with MIC values ranging from 0.06 to $0.25 \mu \mathrm{g} / \mathrm{mL}$. Mupirocin was later developed for topical usage [19-22].

Several siderophores of hydroxamate, catecholate or phenolic scaffolds such as cepabactin [23], pyochelin [24,25], pyoverdines [26], vulnibactin [27], and pseudomonine [28] are produced under iron deficiency by various Pseudomonas species to acquire iron which is essential for cell metabolism and growth $[29,30]$. Studies show that siderophore-antibiotic complexes may be used as a Trojan horse strategy in which the antibiotics utilize the iron-siderophore transporting system as a cellular entry gateway $[31,32]$. Thus far, a few Pseudomonasderived siderophores including ferrocins [33], thioquinolobactin [34], and (+)-(S)-dihydroaeruginioc acid [35] have been reported as active antimicrobial agents.
Our continued exploration of new bioactive compounds from microbial sources led to the isolation of Pseudomonas sp. UIAU-6B from sediments collected from the Oyun river in North Central Nigeria. Herein, we report the isolation and structure elucidation of seven secondary metabolites including five new (1-5), and two known phenolic siderophores (6 and 7) [28,36,37], together with their antimicrobial activities against vancomycin-sensitive Enterococcus faecium VS144754 and Mycobacterium tuberculosis strain H37Rv. A plausible biosynthetic hypothesis is proposed towards the new compounds $\mathbf{1}-\mathbf{5}$.

\section{Results and Discussion}

The preliminary LC-MS analysis of the methanolic extract from a small-scale culture of Pseudomonas sp. UIAU-6B in modified SGG medium indicated the presence of some interesting peaks with molecular ions which gave no hits when they were searched in natural product databases (Antibase). At the same time, the ${ }^{1} \mathrm{H}$ NMR fingerprints suggested the presence of interesting aromatic compounds and led to a decision to undertake large-scale fermentation. The total crude extract $(8.2 \mathrm{~g})$ was subsequently subjected to a combination of fractionations (Kupchan partition and MPLC), and purification by reversedphase semipreparative HPLC to obtain five new secondary metabolites 1-5 including pseudomonin A-C (1-3) and pseudomobactins A and B (4 and 5). The two known compounds, pseudomonine (6) and salicylic acid (7) were also isolated as the major constituents of the extracts and their structures were determined by analysis of HRESIMS, 1D and 2D NMR data (see Figure 1 and Supporting Information File 1 for details) which were comparable with those reported in the literature [28,36,37].

Pseudomonin A (1) was isolated as a yellowish compound. The molecular formula of $\mathrm{C}_{11} \mathrm{H}_{15} \mathrm{O}_{4} \mathrm{~N}_{2}$ with 6 degrees of unsatura-<smiles>[R]NC(=O)[C@H](N)[C@H]([2H])OC(=O)c1ccccc1O</smiles>

$1 \mathrm{R}=\mathrm{H}$

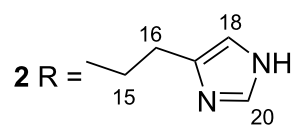<smiles>[R]=CC[13CH2]c1ccccc1</smiles><smiles>[R]NC(=O)[C@H]1N=C(c2ccccc2O)O[13C]1[Y]</smiles><smiles>[R]</smiles><smiles>CC1=CN(CCc2c[nH]cn2)C(=O)[C@H]1NC(=O)c1ccccc1O</smiles>

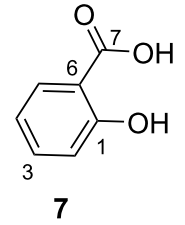

Figure 1: Structures of the new phenolic siderophores 1-5, pseudomonine (6), and salicylic acid (7). 
tion was established by high-resolution ESI-Orbitrap-MS that revealed a molecular ion at $\mathrm{m} / \mathrm{z} 237.0874$ (calcd for $\mathrm{C}_{11} \mathrm{H}_{13} \mathrm{~N}_{2} \mathrm{O}_{4}{ }^{-}, 237.0880$ ). A thorough analysis of ${ }^{1} \mathrm{H}$ and $2 \mathrm{D}$ NMR data (see Table 1 and Supporting Information File 1) showed four aromatic methines, two aliphatic methines, one methyl, and four quaternary carbons signals at $\delta_{\mathrm{C}} 162.9(\mathrm{C}-1)$, $113.2(\mathrm{C}-6), \delta_{\mathrm{C}} 170.0 .0(\mathrm{C}-7)$, and $\delta_{\mathrm{C}} 169.4(\mathrm{C}-10)$.

The downfield methine proton signals at $\delta_{\mathrm{H}} 6.96(\mathrm{~d}, J=8.7$, $1.8 \mathrm{~Hz}, \mathrm{H}-2), 7.52$ (td, $J=8.7,7.2,1.8 \mathrm{~Hz}, \mathrm{H}-3), 6.94(\mathrm{td}, J=$ $8.7,1.8 \mathrm{~Hz}, \mathrm{H}-4)$, and $\delta_{\mathrm{H}} 7.99(\mathrm{dd}, J=8.1,1.8 \mathrm{~Hz}, \mathrm{H}-5)$ were consistent with a 1,2-disubstituted aromatic benzene ring of a salicylic acid unit, confirmed by long-range correlations observed in the HMBC spectrum from $\mathrm{H}-2, \mathrm{H}-4$ to $\mathrm{C}-6\left(\delta_{\mathrm{C}} 113.2\right)$, and $\mathrm{H}-5$ to the quaternary carbon $\mathrm{C}-7\left(\delta_{\mathrm{C}} 170.0\right)$. On the other hand, the COSY spectrum confirmed the presence of a $\mathrm{CH}_{3}-\mathrm{CH}-\mathrm{CH}$ spin system $\left(\mathrm{H}_{3}-12, \mathrm{H}-11\right.$, and $\left.\mathrm{H}-9\right)$ reminiscent of a threonine unit. Remarkably, this unit was found to be attached in "reverse" fashion compared to the isoxazolidinone unit in compound 6. The connection via an ester bond of the oxygenated $\mathrm{sp}^{3}$ methine $\mathrm{C}-11\left(\delta_{\mathrm{C}} 71.1\right)$ with the carbonyl group of salicylic acid (C-7) was supported by a HMBC cross-peak from $\mathrm{H}-11\left(\delta_{\mathrm{H}} 5.61\right)$ to $\mathrm{C}-7\left(\delta_{\mathrm{C}} 170.0\right)$, and thus confirmed the structure of pseudomonin A (1).
Pseudomonin B (2) was isolated as a yellowish solid whose HRESI mass spectrum gave a molecular ion at $\mathrm{m} / \mathrm{z} 333.1561$ $[\mathrm{M}+\mathrm{H}]^{+}$that corresponded to a molecular formula of $\mathrm{C}_{16} \mathrm{H}_{20} \mathrm{~N}_{4} \mathrm{O}_{4}$ (calcd for $\mathrm{C}_{16} \mathrm{H}_{21} \mathrm{~N}_{4} \mathrm{O}_{4}{ }^{+}$, 333.1557) with 9 degrees of unsaturation. The detailed analysis of ${ }^{1} \mathrm{H}$ and 2D NMR spectra (see Table 1 and Supporting Information File 1) suggested the presence of both, the salicylic acid $(\mathrm{H}-2 / \mathrm{H}-3 / \mathrm{H}-4 /$ $\mathrm{H}-5)$ and the linear threonine subunits found in $\mathbf{1}$, which were supported by the HMBC correlations shown in Figure 2. The major difference in comparison with compound $\mathbf{1}$ was the presence of a histamine subunit (H-15 to H-20), whose identity was established by COSY correlations observed between $\mathrm{H}-15$ and H-16 and the key HMBC correlations depicted in Figure 2.

Pseudomonin C (3) was isolated as white amorphous solid. Its molecular formula of $\mathrm{C}_{19} \mathrm{H}_{22} \mathrm{~N}_{2} \mathrm{O}_{4}$ was deduced from the analysis of its HRESI mass spectrum $\left(\mathrm{m} / z 343.1653[\mathrm{M}+\mathrm{H}]^{+}\right.$, calcd for $\mathrm{C}_{19} \mathrm{H}_{23} \mathrm{~N}_{2} \mathrm{O}_{4}{ }^{+}, 343.1652$ ) accounting for ten degrees of unsaturation. A prominent peak at $\mathrm{m} / \mathrm{z} 325.1551$ $\left[(\mathrm{M}+\mathrm{H}-\mathrm{OH}]^{+}\right.$(calcd for $\mathrm{C}_{19} \mathrm{H}_{21} \mathrm{~N}_{2} \mathrm{O}_{3}{ }^{+}, 325.1547$ ) due to a facile loss of $\mathrm{H}_{2} \mathrm{O}$ from the molecular ion was observed. A thorough inspection of 1D and 2D spectra (see Table 1 and Supporting Information File 1) confirmed the resonance signals characteristic of both, the salicylic acid (H-2 to H-5) and the linear

Table 1: ${ }^{1} \mathrm{H}$ and ${ }^{13} \mathrm{C}$ NMR data of pseudomonin A-C (1-3). ${ }^{\mathrm{a}}$

\begin{tabular}{|c|c|c|c|c|c|c|}
\hline \multirow[b]{2}{*}{ position } & \multicolumn{2}{|c|}{ compound 1} & \multicolumn{2}{|c|}{ compound 2} & \multicolumn{2}{|c|}{ compound $\mathbf{3}$} \\
\hline & $\delta_{C}$, type & $\delta_{H}(J$ in $\mathrm{Hz})$ & $\delta_{C}$, type & $\delta_{\mathrm{H}}(J$ in $\mathrm{Hz})$ & $\delta_{\mathrm{C}}$, type & $\delta_{H}(J$ in $H z)$ \\
\hline 1 & 162.9, C & & $162.8, \mathrm{C}$ & & $162.8, \mathrm{C}$ & \\
\hline 2 & 118.2, $\mathrm{CH}$ & 6.96, dd $(8.7,1.8)$ & 118.4, CH & $6.96, d(8.7)$ & $118.4, \mathrm{CH}$ & $6.98, \mathrm{~m}$ \\
\hline 3 & 137.2, $\mathrm{CH}$ & $7.52, \operatorname{td}(8.7,1.8)$ & $137.5, \mathrm{CH}$ & $7.52, \mathrm{td}(8.7,1.7)$ & 137.4, $\mathrm{CH}$ & $7.54, \operatorname{td}(8.7,1.8)$ \\
\hline 4 & 120.2, CH & $6.94, \operatorname{td}(8.7,1.8)$ & 120.6, CH & $6.94, \mathrm{dd}(8.7,1.7)$ & $120.5, \mathrm{CH}$ & $6.95, \mathrm{~m}$ \\
\hline 5 & 131.6, CH & 7.99, dd $(8.7,1.8)$ & $131.7, \mathrm{CH}$ & 7.95, dd $(8.7,1.7)$ & 131.7, $\mathrm{CH}$ & 7.98, dd $(8.7,1.8)$ \\
\hline 6 & 113.2, C & & 113.1, C & & 113.2, C & \\
\hline 7 & $170.0, \mathrm{C}$ & & $169.9, \mathrm{C}$ & & $170.0, \mathrm{C}$ & \\
\hline 9 & $57.6, \mathrm{CH}$ & $4.20, d(6.5)$ & $57.7, \mathrm{CH}$ & $4.21, d(6.5)$ & $57.8, \mathrm{CH}$ & $4.13, d(6.5)$ \\
\hline 10 & $169.4, \mathrm{C}$ & & $167.7, \mathrm{C}$ & & 167.2, C & \\
\hline 11 & 71.1, $\mathrm{CH}$ & 5.67, qd $(6.6,6.5)$ & $71.0, \mathrm{CH}$ & 5.61, qd $(6.6,6.5)$ & 71.3, $\mathrm{CH}$ & $5.53, \mathrm{dq}(6.5,6.5)$ \\
\hline 12 & $16.7, \mathrm{CH}_{3}$ & $1.54, \mathrm{~d}(6.6)$ & $17.0, \mathrm{CH}_{3}$ & $1.49, \mathrm{~d}(6.6)$ & $16.9, \mathrm{CH}_{3}$ & $1.43, \mathrm{~d}(6.5)$ \\
\hline 15 & & & 39.3, $\mathrm{CH}_{2}$ & $\begin{array}{l}\text { 3.62, dt }(13.8,6.8) \\
3.52 \text {, dt }(13.8,6.8)\end{array}$ & $42.1, \mathrm{CH}_{2}$ & $\begin{array}{l}3.44, \mathrm{dt}(13.7,7.2) \\
3.64, \mathrm{dt}(13.7,7.2)\end{array}$ \\
\hline 16 & & & $25.3, \mathrm{CH}_{2}$ & $2.92, \mathrm{~m}$ & $36.1, \mathrm{CH}_{2}$ & $2.79, \mathrm{~m}$ \\
\hline 17 & & & $132.5, \mathrm{C}$ & & $140.0, \mathrm{C}$ & \\
\hline 18 & & & $117.5 \mathrm{CH}$ & 7.33, d (0.6) & & \\
\hline 20 & & & $135.0, \mathrm{CH}$ & $8.73, d(0.6)$ & & \\
\hline $18^{\prime} / 22$ & & & & & $129.5, \mathrm{CH}$ & $7.16, \mathrm{~m}$ \\
\hline $19^{\prime} / 21$ & & & & & 129.6, CH & $7.22, \mathrm{~m}$ \\
\hline 20 & & & & & $127.5, \mathrm{CH}$ & $7.14, \mathrm{~m}$ \\
\hline
\end{tabular}

aspectra acquired at $600 \mathrm{MHz}$ in $\mathrm{CD}_{3} \mathrm{OD}$ for ${ }^{1} \mathrm{H} \mathrm{NMR}$ and at $150 \mathrm{MHz}$ in $\mathrm{CD}_{3} \mathrm{OD}$ for ${ }^{13} \mathrm{C} \mathrm{NMR}$. 

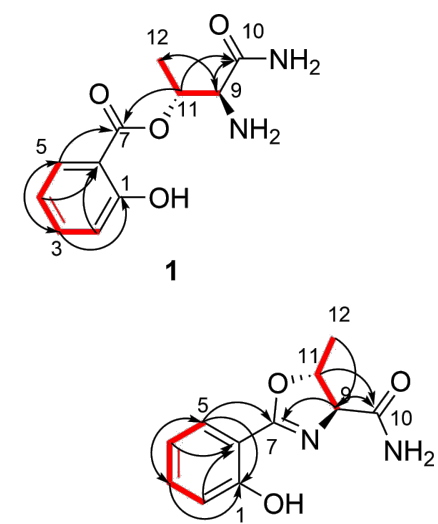

4

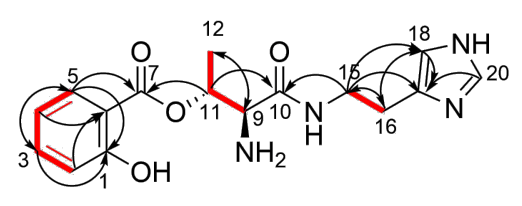

2

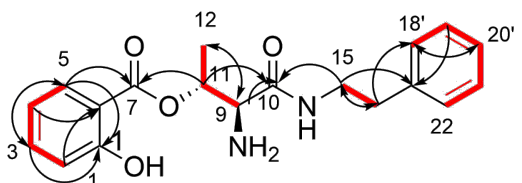

3

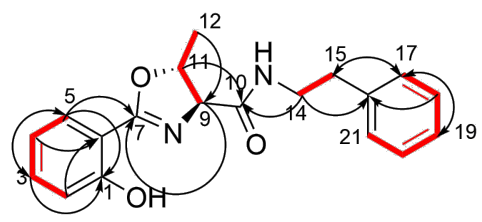

5

HMBC

cosY

Figure 2: Key $\mathrm{HMBC}$ and ${ }^{1} \mathrm{H}-{ }^{1} \mathrm{H}$ COSY correlations.

threonine (H-9 to $\left.\mathrm{H}_{3}-12\right)$ conjugate present in compounds $\mathbf{1}$ and $\mathbf{2}$, and also displayed a new set of signals compatible with the replacement of the histamine unit in $\mathbf{2}$ with a phenylethylamine moiety (H-15 to H-22). This was supported by the COSY and HMBC correlations shown in Figure 2, and thus confirmed the structure of pseudomonin C (3).

Pseudomobactin A (4) was obtained as a reddish solid. The HRESI mass spectrum revealed a molecular ion at $\mathrm{m} / \mathrm{z} 221.0923$
([M $+\mathrm{H}]^{+}$, calcd for $\left.\mathrm{C}_{11} \mathrm{H}_{13} \mathrm{~N}_{2} \mathrm{O}_{3}{ }^{+}, 221.0921\right)$ corresponding to a molecular formula of $\mathrm{C}_{11} \mathrm{H}_{12} \mathrm{~N}_{2} \mathrm{O}_{3}$ with seven degrees of unsaturation. The integration of the ${ }^{1} \mathrm{H}$ NMR spectrum (see Table 2 and Supporting Information File 1) identified two spin systems consistent with the presence of the 1,2-disubstituted aromatic ring of salicylic acid in compounds $\mathbf{1}-\mathbf{3}$ and a threonine unit (H-9 to H-12) that differed from compounds 1-3 due to the observed deshielded chemical shifts of the methine carbons C-9 $\left(\delta_{C} 75.5\right)$ and $\mathrm{C}-12\left(\delta_{\mathrm{C}} 21.4\right)$, suggestive of the presence of an

\begin{tabular}{|c|c|c|c|c|}
\hline \multirow[b]{2}{*}{ position } & \multicolumn{2}{|c|}{ compound 4} & \multicolumn{2}{|c|}{ compound 5} \\
\hline & $\delta_{C}$, type & $\delta_{\mathrm{H}},(J$ in $\mathrm{Hz})$ & $\delta_{C}$, type & $\delta_{\mathrm{H}},(J$ in $\mathrm{Hz})$ \\
\hline 1 & 161.1, C & & 161.1, C & \\
\hline 2 & 117.7, $\mathrm{CH}$ & $6.96, d(8.3)$ & 117.7, $\mathrm{CH}$ & $6.99, \mathrm{~d}(8.3)$ \\
\hline 3 & 135.0, $\mathrm{CH}$ & $7.41, \mathrm{td}(8.3,1.7)$ & $135.1, \mathrm{CH}$ & $7.43, \mathrm{td}(8.3,1.6)$ \\
\hline 4 & $119.9, \mathrm{CH}$ & $6.90, \mathrm{td}(7.4,1.7)$ & $120.0, \mathrm{CH}$ & $6.92, \mathrm{t}(7.4,1.7)$ \\
\hline 5 & $129.5, \mathrm{CH}$ & $7.68, \mathrm{dd}(7.4,1.7)$ & $129.5, \mathrm{CH}$ & $7.67, \mathrm{dd}(7.4,1.7)$ \\
\hline 6 & 111.6, C & & $111.6, \mathrm{C}$ & \\
\hline 7 & 167.8, C & & 168.0, C & \\
\hline 9 & $75.5, \mathrm{CH}$ & $4.46, d(7.3)$ & $75.8, \mathrm{CH}$ & $4.38, \mathrm{~d}(7.3)$ \\
\hline 10 & 175.6, C & & $172.9, \mathrm{C}$ & \\
\hline 11 & $80.6, \mathrm{CH}$ & 4.90, qd $(6.3,7.3)$ & $80.6, \mathrm{CH}$ & $4.78, \mathrm{dq}(6.3,7.3)$ \\
\hline 12 & $21.4, \mathrm{CH}_{3}$ & $1.57, \mathrm{~d}(6.3)$ & $21.3, \mathrm{CH}_{3}$ & $1.51, \mathrm{~d}(6.3)$ \\
\hline 14 & & & $41.9, \mathrm{CH}_{2}$ & $3.44, \mathrm{dt}(13.6,7.2), 3.51, \mathrm{dt}(13.6,7.2)$ \\
\hline 15 & & & $36.3, \mathrm{CH}_{2}$ & $2.82, \mathrm{t}(7.2)$ \\
\hline 16 & & & $140.2, \mathrm{C}$ & \\
\hline $17 / 21$ & & & $129.9, \mathrm{CH}$ & $7.20, \mathrm{~m}$ \\
\hline $18 / 20$ & & & $129.5, \mathrm{CH}$ & $7.22, \mathrm{~m}$ \\
\hline 19 & & & $127.3, \mathrm{CH}$ & $7.15, \mathrm{~m}$ \\
\hline
\end{tabular}

aSpectra acquired at $600 \mathrm{MHz}$ in $\mathrm{CD}_{3} \mathrm{OD}$ for ${ }^{1} \mathrm{H} \mathrm{NMR}$ and at $150 \mathrm{MHz}$ in $\mathrm{CD}_{3} \mathrm{OD}$ for ${ }^{13} \mathrm{C} \mathrm{NMR}$. 
oxazoline ring similar to that found in vulnibactin [27]. The key HMBC cross-peaks (Figure 2 and Supporting Information File 1) from $\mathrm{H}-9\left(\delta_{\mathrm{H}} 4.46, J=7.3 \mathrm{~Hz}, \mathrm{~d}\right)$ and $\mathrm{H}-11\left(\delta_{\mathrm{H}} 4.90\right.$, qd, $J=6.3,7.3 \mathrm{~Hz})$ to carboxamide $\mathrm{C}-10\left(\delta_{\mathrm{C}} 175.6\right)$ and $\mathrm{C}-7$ $\left(\delta_{C} 167.8\right)$, confirmed the proposed structure which we named pseudomobactin A.

Compound 5 was obtained as a reddish solid. The HRESIMS gave a prominent molecular ion at $\mathrm{m} / z 325.1550\left([\mathrm{M}+\mathrm{H}]^{+}\right.$corresponding to a molecular formula of $\mathrm{C}_{19} \mathrm{H}_{20} \mathrm{~N}_{2} \mathrm{O}_{3}$ with eleven degrees of unsaturation. The information afforded by integrating the signals of the ${ }^{1} \mathrm{H}$ NMR and the full 2D spectra (Table 2 and Supporting Information File 1) of compound 5 showed resonance signals consistent with compound 4 connected to the same 2-phenylethylamine moiety present in $\mathbf{3}$ (H-14 to $\mathrm{H}-21$ ). This was supported by HMBC cross-peaks (Figure 2) between the diastereotopic protons $\mathrm{H}_{2}-14$ and carboxamide $\mathrm{C}-10\left(\delta_{\mathrm{C}} 172.9\right)$ and the quaternary carbon $\mathrm{C}-16$ $\left(\delta_{\mathrm{C}} 140.2\right)$, between $\mathrm{H}_{2}-15$ and $\mathrm{H}-18 / 20$ to the quaternary carbon $\mathrm{C}-16$, and a strong correlation from $\mathrm{H}-15$ and $\mathrm{H}-19$ to $\mathrm{C}-17 / 20\left(\delta_{\mathrm{C}} 129.9\right)$. The new oxazoline derivative 5 was named pseudomonbactin B.
The absolute configuration of the threonine residue in compounds 1-5 was assigned as L, based on the derivatization with Marfey's reagent of compound $\mathbf{2}$ and $\mathbf{4}$ hydrolysates, which represented the two distinctive structural scaffolds and chemical shifts followed by HPLC analysis of the derivatized amino acid residuals in the hydrolysate and threonine standards (see Supporting Information File 1).

The biosynthesis hypotheses of compounds 1-5 were proposed to have originated as an extension of the reported pseudomonine (6) biosynthesis [37-40] via the salimethyloxazolinylthioester intermediate 8 (Figure 3 ). We speculated that compounds 1-3 occur through deviation of the salimethyloxazolinyl-thioester intermediate $\mathbf{8}$ from the assembly line via an unusually facile $\mathrm{C}-\mathrm{N}$-bond opening of the ring to generate an ester bond, and followed directly by amination $\left(+\mathrm{NH}_{3}\right)$, the addition of histamine and phenethylamine units to form compounds 1, 2, and 3, respectively (Figure 3). Biochemical studies show that histamine and phenethylamine moieties were produced from histidine and phenylalanine substrates by a decarboxylase enzyme [41-43]. Pseudomobactin A (4) was proposed logically to have formed through direct amination of the

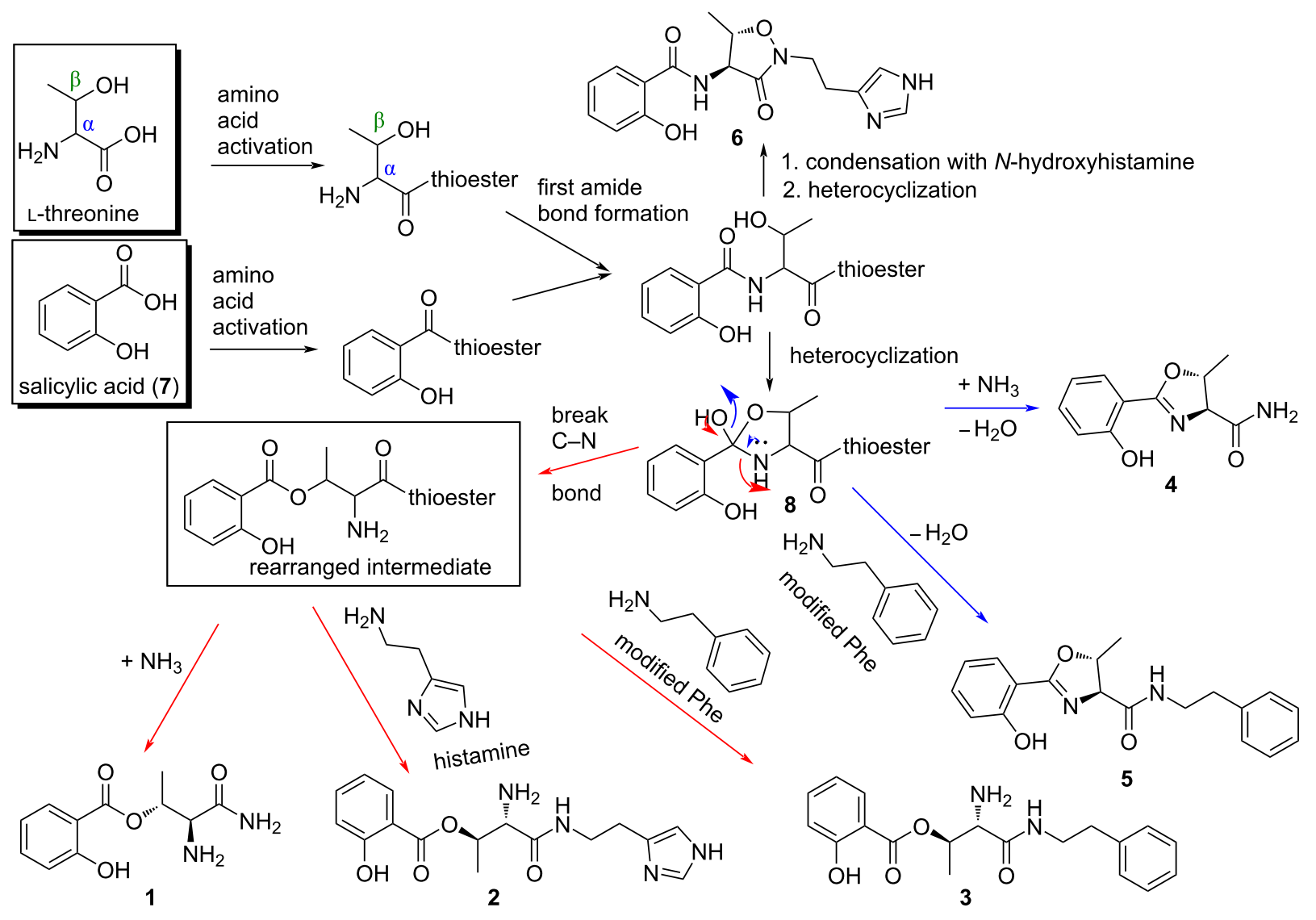

Figure 3: Plausible biosynthetic hypotheses of compounds 1-5. 
unstable salimethyloxazolinyl-thioester intermediate followed by dehydration [44]. The incorporation of the decarboxylated phenylalanine by a nucleophilic unit to the intermediate salimethyloxazolinyl-thioester resulted in the formation of compound 5 without a rearrangement to isooxazolidinone owing to lack of $\mathrm{N}-\mathrm{OH}$ in the phenylalanine unit [40].

\section{Biological evaluation}

Compounds 1-7 were evaluated for their antimicrobial activities against methicillin-resistant Staphylococcus aureus (MRSA), methicillin-sensitive Staphylococcus aureus (MSSA), Escherichia coli, Acinetobacter Bahmani, vancomycin-resistant E. faecium VanA15167, vancomycin-sensitive E. faecium VS144756, and M. tuberculosis H37Rv (see Table S8 in Supporting Information File 1). Compound 4 was the most potent against Vancomycin-sensitive E. faecium VS144754, with a MIC value in a range of $8-16 \mu \mathrm{g} / \mathrm{mL}$, followed by compounds 3 and 5, which showed MIC values of 16 and $32 \mu \mathrm{g} / \mathrm{mL}$, respectively. Additionally, compounds $\mathbf{2}$ and $\mathbf{3}$ exhibited moderate antitubercular activity with MICs of 7.8 and $15.6 \mu \mathrm{g} / \mathrm{mL}$, respectively. Besides, compound 5 showed low activity (MIC of $125 \mu \mathrm{g} / \mathrm{mL}$ ) against the latter pathogen. None of the compounds inhibited the growth of E. coli, A. baumannii, MRSA, MSSA, or E. faecium VanA15167 at the highest concentration $(64 \mu \mathrm{g} / \mathrm{mL})$ tested (see Supporting Information File 1).

\section{Conclusion}

In summary, we have isolated seven natural products, including five new phenolic siderophores (1-5) that have not been reported in the literature and their biosynthetic pathways were proposed as a rational extension of the previously reported metabolite, pseudomonine (6), one of the major constituents of the extract from the culture broth of Pseudomonas sp. UIAU6B. The new compounds 1-5 are interesting chemical entities consisting of scaffolds with different functionalities that could be exploited for further biological investigation and structure-activity relationship (SAR) studies. To the best of our knowledge, the breakage of the $\mathrm{C}-\mathrm{N}$ bond of the salimethyloxazolinyl-thioester intermediate leading to an ester bond that resulted in the formation of compounds $\mathbf{1}-\mathbf{3}$ constitutes new plausible hypotheses not previously reported in natural product biosynthesis.

\section{Experimental}

\section{General experimental procedures}

IR spectra were acquired on a Perkin Elmer Spectrum Two FT-IR spectrometer equipped with an ATR diamond cell. Optical rotations were measured on an ADP 410 digital Polarimeter (Bellingham + Stanley Ltd, United Kingdom). NMR spectra were recorded on Bruker AVANCE III spectrometers at 500/600 MHz for ${ }^{1} \mathrm{H}$ NMR and $125 / 150 \mathrm{MHz}$ for
${ }^{13} \mathrm{C}$ NMR operating with a helium-cooled cryoprobe and a liquid nitrogen 'Prodigy' cryoprobe, respectively. ${ }^{1} \mathrm{H}$ and ${ }^{13} \mathrm{C}$ chemical shifts were referenced to the residual non-deuterated solvent peak (3.31 and $49.1 \mathrm{ppm}$ for $\mathrm{CD}_{3} \mathrm{OD}$ ). The multiplicities of ${ }^{13} \mathrm{C}$ NMR were determined by an edited heteronuclear single quantum coherence (HSQC) experiment. HRESIMS spectra were obtained using a Thermo Instruments MS system (LTQ XL/LTQ Orbitrap Discovery) coupled to a thermo instruments HPLC system (Accela PDA detector, Accela PDA autosampler, and Accela pump) or an Agilent 6540 in ESI-TOF MS coupled to an HPLC Agilent 1290 Infinity equipped with a diode array detector (DAD). Chromatographic fractionation was carried out on a Reveleris preparative flash system equipped with a reversed-phase Phenomenex strata ${ }^{\circledR} \mathrm{C} 18$-E cartridge (55 $\mu \mathrm{m}, 70 \AA, 2 \mathrm{~g} / 12 \mathrm{~mL}$ ). HPLC purification was done with an Agilent HPLC apparatus (1200 series) equipped with a binary pump, diode array detector (G1315B), sunfire reversed-phase column C18 (5 $\mu \mathrm{m}, 10 \times 250 \mathrm{~mm})$, Phenomenex C18 $(5 \mu \mathrm{m}$, $9.4 \times 250 \mathrm{~mm})$, or ACE C18 $(5 \mu \mathrm{m}, 9.4 \times 250 \mathrm{~mm})$ columns, and a mobile phase solvent gradient consisting of $\mathrm{H}_{2} \mathrm{O}$ (Milli-Q filter water $18 \mathrm{M} \Omega \cdot \mathrm{cm}$, Millipore, Germany), $100 \% \mathrm{MeOH}$ (Sigma-Aldrich, UK), and TFA (Sigma-Aldrich, UK).

\section{Bacterial isolation and identification}

The bacterial strain was isolated from soil sediments collected from the Oyun river in North Central Nigeria $\left(8.4799^{\circ} \mathrm{N}\right.$, $\left.4.5418^{\circ} \mathrm{W}\right)$. The sediment samples were air-dried at room temperature for $48 \mathrm{~h}$. Ten grams (dry weight equivalent) were suspended in $100 \mathrm{~mL}$ of sterile distilled water, vortexed at high speed, and $1 \mathrm{~mL}$ of diluent was serially diluted $\left(10^{-2}\right.$ and $\left.10^{-4}\right)$. Isolation of the bacterium (UIAU-6B) using a spread plate technique was performed by inoculating an $0.1 \mathrm{~mL}$ aliquot on pseudomonas agar base augmented with cephalosporin-fucidin-cetrimide-selective supplement (Pseudomonas-CFC agar SR0103, Oxoid Ltd., Reading, UK) and incubated at $28{ }^{\circ} \mathrm{C}$ for five days. The pure colony of the UIAU-6B strain was purified by repeated subculture on pseudomonas agar base plates. The strain was identified by analysis of the molecular DNA sequencing of its $16 \mathrm{~S}$ rDNA and the sequence obtained was compared with the Genbank database using the BLAST search of the National Center for Biotechnology Information (NCBI) which confirmed it to be homologous by 99.06\% in the phylogenetic tree as Pseudomonas sp. (see Figure S49A, in Supporting Information File 1).

\section{Fermentation}

The small-scale culture was prepared by inoculating a stock culture of Pseudomonas UIAU-6B (2 mL) in a $1000 \mathrm{~mL}$ baffled Erlenmeyer flask containing $150 \mathrm{~mL}$ modified SGG medium (glycerol $10 \mathrm{~g}$, corn steep powder $2.5 \mathrm{~g}$, peptone $5 \mathrm{~g}$, soluble starch $10 \mathrm{~g}$, yeast extract $2 \mathrm{~g}, \mathrm{CaCO}_{3} 3 \mathrm{~g}, \mathrm{NaCl} 1 \mathrm{~g}$, in $1 \mathrm{~L} \mathrm{H}_{2} \mathrm{O}$, 
$\mathrm{pH}$ adjusted to 7.3) [45]. The flask was left shaking at $160 \mathrm{rpm}$ in a closed system shaker for ten days at $28{ }^{\circ} \mathrm{C}$. Subsequently, $7.5 \mathrm{~g}$ of HP-20 resin were added to the fermentation cultures under sterile conditions and incubated for the next $7 \mathrm{~h}$ at the same shaking conditions. The broth cultures were filtered under vacuum and the HP-20 resin was extracted with methanol $(200 \mathrm{~mL})$ to obtain $1.2 \mathrm{~g}$ of crude extract from which a $0.5 \mathrm{mg} / \mathrm{mL}$ solution was prepared for preliminary LC-MS chemical profiling.

Large-scale cultures $(6000 \mathrm{~mL})$ were prepared by inoculating twenty $2000 \mathrm{~mL}$ baffled Erlenmeyer flasks containing $300 \mathrm{~mL}$ modified SGG medium with the seed culture of Pseudomonas UIAU-6B $(50 \mathrm{~mL})$. The seed culture $(50 \mathrm{~mL})$ was prepared by inoculating a $250 \mathrm{~mL}$ baffled Erlenmeyer flask containing a modified SGG medium with a stock culture of Pseudomonas UIAU-6B ( $2 \mathrm{~mL})$ and growth for 3 days. The entire fermentation process employed similar conditions as the small-scale culture.

\section{Extraction and isolation}

After the incubation, $15 \mathrm{~g}$ of HP-20 resin were added to each flask under sterile conditions and allowed to shake for 7 hours before the HP20 resin was filtered and subsequently extracted with methanol $(3 \times 500 \mathrm{~mL})$ followed by ethyl acetate $(3 \times 300 \mathrm{~mL})$. The combined organic extract was dried under reduced pressure, to yield $8.2 \mathrm{~g}$ of crude extract. The extract (8.2 g) was dissolved in $\mathrm{H}_{2} \mathrm{O}$ and $\mathrm{CH}_{2} \mathrm{Cl}_{2}(700 \mathrm{~mL}, 50 \% \mathrm{v} / \mathrm{v})$ and placed in a separating funnel for $5 \mathrm{~min}$ to allow for proper separation of the constituent mixture between the aqueous $(6.21 \mathrm{~g})$ and organic phases (1.99 g) [46]. The dichloromethane fraction $(1.99 \mathrm{~g})$ was chromatographed on a reversed-phase preparative flash system consisting of a C-18 (KP-C18-HS ${ }^{\mathrm{TM}}$, $40 \times 150 \mathrm{~mm}$ ) stationary phase cartridge equipped with variable UV and ELSD detectors to monitor the run at 210,230 , and $254 \mathrm{~nm}$ ) with the combination of isocratic and linear gradient solvent system $\left(80-20 \% \mathrm{H}_{2} \mathrm{O} / \mathrm{MeOH}\right.$ for $20 \mathrm{~min}$ followed by a linear gradient from $20 \%$ to $50 \% \mathrm{MeOH}$ over $10 \mathrm{~min}, 50 \% \mathrm{MeOH}$ for $5 \mathrm{~min}, 50 \%$ to $70 \%$ $\mathrm{MeOH} / \mathrm{H}_{2} \mathrm{O}$ for $15 \mathrm{~min}, 70 \% \mathrm{MeOH}$ for $5 \mathrm{~min}, 70 \%$ to $100 \%$ $\mathrm{MeOH} / \mathrm{H}_{2} \mathrm{O}$ for $15 \mathrm{~min}$ and $100 \% \mathrm{MeOH}$ over $20 \mathrm{~min}$ ) at a flow rate of $10 \mathrm{~mL} / \mathrm{min}$. Four fractions were obtained: FD1 $\left(0.8 \mathrm{~g}, t_{\mathrm{R}} 8.2-12.0 \mathrm{~min}\right), \mathrm{FD} 2\left(0.35 \mathrm{~g}, t_{\mathrm{R}} 27-40 \mathrm{~min}\right), \mathrm{FD} 3$ $\left(0.24 \mathrm{~g}, t_{\mathrm{R}} 41-57 \mathrm{~min}\right)$, and FD4 (0.45 g, $\left.t_{\mathrm{R}} 58-70 \mathrm{~min}\right)$.

Fraction FD1 (0.8 g) was subjected to reversed-phase semipreparative HPLC on a Sunfire column C18 (5 $\mu \mathrm{m}$, $10 \times 250 \mathrm{~mm}$ ) with a linear gradient of $\mathrm{H}_{2} \mathrm{O} / \mathrm{MeOH} 80-20 \%$ over $30 \mathrm{~min}$ at a flow rate of $2 \mathrm{~mL} / \mathrm{min}$, yielding compounds 7 (70 mg, $\left.t_{\mathrm{R}} 10 \mathrm{~min}\right), 6\left(300 \mathrm{mg}, t_{\mathrm{R}} 15.1 \mathrm{~min}\right)$, and $\mathbf{1}(2.2 \mathrm{mg}$, $\left.t_{\mathrm{R}} 23.4 \mathrm{~min}\right)$.
Fraction FD2 (0.35 g) was purified with the same HPLC solvent system and stationary phase as FD1 to obtain compound 4 (3.9 mg, $\left.t_{\mathrm{R}} 22.2 \mathrm{~min}\right)$.

Fraction FD3 (0.35 g) was subjected to HPLC on a reversedphase Phenomenex column C18 $(5 \mu \mathrm{m}, 10 \times 250 \mathrm{~mm})$ with a mobile phase gradient system of $\mathrm{H}_{2} \mathrm{O} / \mathrm{MeOH} 80-20 \%$ and $0.01 \% \mathrm{TFA}$ for $35 \mathrm{~min}$ at a flow rate of $2 \mathrm{~mL} / \mathrm{min}$ to afford compound 2 (15.3 $\left.\mathrm{mg}, t_{\mathrm{R}} 19.1 \mathrm{~min}\right)$.

The final dichloromethane subfraction FD4 (0.45 g) was rechromatographed by reversed-phase HPLC using a Sunfire column C18 $(5 \mu \mathrm{m}, 10 \times 250 \mathrm{~mm})$ and a variable solvent system starting with $\mathrm{H}_{2} \mathrm{O} / \mathrm{MeOH} 70: 30$ isocratic elution over 5 min, followed by a linear gradient to $100 \% \mathrm{MeOH}$ over $20 \mathrm{~min}$ at a flow rate of $1.8 \mathrm{~mL} / \mathrm{min}$ to yield compounds $3(1.2 \mathrm{mg}$, $\left.t_{\mathrm{R}} 16.8 \mathrm{~min}\right)$ and $5\left(1.8 \mathrm{mg}, t_{\mathrm{R}} 18.9 \mathrm{~min}\right)$.

Pseudomonin A (1): yellowish oil; $[\alpha]_{\mathrm{D}}^{25}-9.5(c 0.02, \mathrm{MeOH})$; $\mathrm{UV}(\mathrm{MeOH}) \lambda_{\max }, \mathrm{nm}(\log \varepsilon): 276$ (3.23); IR $\left(\mathrm{cm}^{-1}\right) v_{\max }$ : 3333, 1677 1660, 1538, 1493, 1203, 1138; NMR data, see Table 1; HRESIMS $(\mathrm{m} / \mathrm{z})$ : $[\mathrm{M}-1]^{-}$calcd for $\mathrm{C}_{11} \mathrm{H}_{13} \mathrm{~N}_{2} \mathrm{O}_{4}$, 237.0880; found, 237.0874, $\Delta=-2.53 \mathrm{ppm}$.

Pseudomonin B (2): yellowish oil; $[\alpha]_{\mathrm{D}}{ }^{25}-13.3$ (c 0.05 , $\mathrm{MeOH}) ; \mathrm{UV}(\mathrm{MeOH}) \lambda_{\max }, \mathrm{nm}(\log \varepsilon): 297$ (3.64); IR (cm-1) $v_{\max }: 3137,1673,1660$; NMR data, see Table 1; HRESIMS $(m / z):[\mathrm{M}+\mathrm{H}]^{+}$calcd for $\mathrm{C}_{16} \mathrm{H}_{21} \mathrm{O}_{4} \mathrm{~N}_{4}, 333.1557$; found $333.1561, \Delta=1.20 \mathrm{ppm}$.

Pseudomonin C (3): white amorphous solid; $[\alpha]_{\mathrm{D}}{ }^{25}-45.6$ (c 0.02, MeOH); UV (MeOH) $\lambda_{\max }, \mathrm{nm}(\log \varepsilon): 299$ (3.85); IR $\left(\mathrm{cm}^{-1}\right) v_{\max }: 3341,2927,1670,1633,1205$; NMR data, see Table 1; HRESIMS $(\mathrm{m} / \mathrm{z}):[\mathrm{M}+\mathrm{H}]^{+}$calcd for $\mathrm{C}_{19} \mathrm{H}_{23} \mathrm{~N}_{2} \mathrm{O}_{4}$, 343.1652; found, 343.1653, $\Delta=2.01 \mathrm{ppm}$.

Pseudomobactin A (4): yellow amorphous solid; $[\alpha]_{\mathrm{D}}{ }^{25}-17.7$ (c 0.05, MeOH); UV (MeOH) $\lambda_{\max }, \mathrm{nm}(\log \varepsilon): 260$ (3.59), 302 (4.12); IR ( $\left.\mathrm{cm}^{-1}\right) v_{\max }: 3320,2930,1675,1638$; NMR data, see Table 2; HRESIMS $(\mathrm{m} / \mathrm{z})$ : $[\mathrm{M}+\mathrm{H}]^{+}$calcd for $\mathrm{C}_{11} \mathrm{H}_{13} \mathrm{~N}_{2} \mathrm{O}_{3}$, 221.0921; found, 221.0923, $\Delta=0.90 \mathrm{ppm}$.

Pseudomobactin B (5): white amorphous solid; $[\alpha]_{\mathrm{D}}{ }^{25}-28.8$ (c 0.03, MeOH); UV (MeOH) $\lambda_{\max }, \mathrm{nm}(\log \varepsilon): 267$ (3.19); IR $\left(\mathrm{cm}^{-1}\right) v_{\max }: 3320,2930,1674,1638,1205$; NMR data, see Table 2; HRESIMS $(\mathrm{m} / \mathrm{z})$ : $[\mathrm{M}+\mathrm{H}]^{+}$calcd for $\mathrm{C}_{19} \mathrm{H}_{21} \mathrm{~N}_{2} \mathrm{O}_{3}$, 325.1547 ; found, $325.1550, \Delta=0.92 \mathrm{ppm}$.

\section{Marfey's analysis}

Samples of compound $2(150 \mu \mathrm{g})$ and $4(150 \mu \mathrm{g})$ were dissolved separately in $2 \mathrm{M} \mathrm{HCl}(100 \mu \mathrm{L})$ and heated at $100{ }^{\circ} \mathrm{C}$ in 
sealed vials for $16 \mathrm{~h}$. The hydrolysates were concentrated at $40{ }^{\circ} \mathrm{C}$ to dryness under a nitrogen stream. The hydrolysates were treated with $1 \mathrm{M} \mathrm{NaHCO}_{3}$ solution $(20 \mu \mathrm{L})$ and $1 \%$ solution of L-FDAA (Marfey's reagent, 1-fluoro-2-4-dinitrophenyl5 -L-alanine amide) in acetone $(40 \mu \mathrm{L})$. The reaction mixtures were gently heated at $40{ }^{\circ} \mathrm{C}$ for $1 \mathrm{~h}$, after which the solutions were neutralized by the addition of $1 \mathrm{M} \mathrm{HCl}(20 \mu \mathrm{L})$, diluted with acetonitrile $(100 \mu \mathrm{L})$, and filtered through a PTFE membrane filter $(0.45 \mu \mathrm{m})$. The standard amino acids (D-Thr, L-Thr, and L-allo-Thr) were subjected to derivatization with L-FDAA by using the same method previously described. For the HPLC analysis, mixtures of the standard amino acid derivatized solution $(5 \mu \mathrm{L})$, compound $2(5 \mu \mathrm{L})$ and $4(5 \mu \mathrm{L})$ hydrolysates were analyzed by injecting into an HPLC Agilent 1260 Infinity instrument coupled with a Phenomenex $\mathrm{C} 18$ analytical column $(5 \mu \mathrm{m}, 4.6 \times 150 \mathrm{~mm})$ maintained at $40{ }^{\circ} \mathrm{C}$. The mobile phase solvents comprised a mixture of A $(100 \%$ water, $0.1 \% \mathrm{FA})$ and B ( $100 \%$ acetonitrile, $0.1 \% \mathrm{FA})$, with a linear gradient elution mode 10 to $65 \% \mathrm{CH}_{3} \mathrm{CN}$ for 50 min and $65-100 \% \mathrm{CH}_{3} \mathrm{CN}$ over $20 \mathrm{~min}$ at a flow rate of $1.0 \mathrm{~mL} / \mathrm{min}$ and monitored by a diode array HPLC detector at $340 \mathrm{~nm}$. The HPLC traces were aligned and visualized using data analysis as shown in Figure S47 (Supporting Information File 1). Retention times (min) for the derivatized (L-FDAA) threonine standards and for the observed peaks in the HPLC trace of each L-FDAA-derivatized hydrolysis product under the reported conditions were as follows: retention times of standards: L-Thr: 19.62, D-Thr: 22.47, L-allo-Thr: 19.83. Retention time ( $\mathrm{min}$ ) for the derivatized (L-FDAA) threonine presents in 2: L-Thr: 19.63. Retention time (min) for the derivatized (L-FDAA) threonine presents in 4: $\mathrm{L}-\mathrm{Thr}$ : 19.64 .

\section{Supporting Information}

HRESIMS profiles and copies of NMR spectra for compounds 1-7 in $\mathrm{CD}_{3} \mathrm{OD}$ including the NMR table of 6 and $\mathbf{7}$ and copies of UV and IR of compounds 1-5. Phylogenetic tree showing Pseudomonad sp. DNA sequence of the bacterial strain UIAU-6B.

Chromatographic profiles of the compounds derivatized with L-FDAA. Photo of Pseudomonad sp. growing on ISP2 an agar plate. Minimum inhibitory concentration of 1-7 for vancomycin-sensitive Enterococcus faecium VS144754 and Mycobacterium tuberculosis H37Rv. Experimental procedure for antimicrobial assays.

\section{Supporting Information File 1}

Additional analytical and experimental information. [https://www.beilstein-journals.org/bjoc/content/ supplementary/1860-5397-17-156-S1.pdf]

\section{Acknowledgements}

We thank Russell Gray, Subha Arjuna, and Shan Wang of the Marine Biodiscovery Centre, Aberdeen for assisting in NMR, mass spectrometry and Marfey analyses, respectively. We also appreciate the support of Dr. Soji Fakoya and Blessing Akinboyo of Ondo State University of Science and Technology, Okitipupa, Nigeria, for their support in the collection of sediments.

\section{Funding}

This work was supported by funding from TETFund, Nigeria for a University Senate Based research.

\section{ORCID ${ }^{\circledR}$ iDs}

Emmanuel T. Oluwabusola - https://orcid.org/0000-0003-3153-4323 Fernando Reyes - https://orcid.org/0000-0003-1607-5106 Joy E. Rajakulendran - https://orcid.org/0000-0002-4543-8220 Digby F. Warner - https://orcid.org/0000-0002-4146-0930 Marcel Jaspars - https://orcid.org/0000-0002-2426-6028

\section{References}

1. Baker, S.; Thomson, N.; Weill, F.-X.; Holt, K. E. Science 2018, 360, 733-738. doi:10.1126/science.aar3777

2. Dias, D. A.; Urban, S.; Roessner, U. Metabolites 2012, 2, 303-336. doi:10.3390/metabo2020303

3. Harvey, A. Drug Discovery Today 2008, 13, 894-901. doi:10.1016/j.drudis.2008.07.004

4. Weller, D. M. Annu. Rev. Phytopathol. 1988, 26, 379-407. doi:10.1146/annurev.py.26.090188.002115

5. Blanco-Romero, E.; Garrido-Sanz, D.; Rivilla, R.; Redondo-Nieto, M.; Martín, M. Microorganisms 2020, 8, 1740. doi:10.3390/microorganisms8111740

6. Silby, M. W.; Winstanley, C.; Godfrey, S. A. C.; Levy, S. B.; Jackson, R. W. FEMS Microbiol. Rev. 2011, 35, 652-680. doi:10.1111/j.1574-6976.2011.00269.x

7. Raiger lustman, L. J.; Tribelli, P. M.; Ibarra, J. G.; Catone, M. V.; Solar Venero, E. C.; López, N. I. Extremophiles 2015, 19, 207-220. doi:10.1007/s00792-014-0700-7

8. Palleroni, N. J. Antonie van Leeuwenhoek 1997, 72, 3-19. doi:10.1023/a:1000394109961

9. Gajbhiye, M. H.; Kapadnis, B. P. Biocontrol Sci. Technol. 2016, 26, 1451-1470. doi:10.1080/09583157.2016.1213793

10. Harrison, L.; Teplow, D. B.; Rinaldi, M.; Strobel, G. J. Gen. Microbiol. 1991, 137, 2857-2865. doi:10.1099/00221287-137-12-2857

11. Ligon, J. M.; Hill, D. S.; Hammer, P. E.; Torkewitz, N. R.; Hofmann, D.; Kempf, H.-J.; van Pée, K.-H. Pest Manage. Sci. 2000, 56, 688-695. doi:10.1002/1526-4998(200008)56:8<688::aid-ps186>3.0.co;2-v

12. Isnansetyo, A. Int. J. Antimicrob. Agents 2003, 22, 545-547. doi:10.1016/s0924-8579(03)00155-9

13. Cardozo, V. F.; Oliveira, A. G.; Nishio, E. K.; Perugini, M. R.; Andrade, C. G.; Silveira, W. D.; Durán, N.; Andrade, G.; Kobayashi, R. K.; Nakazato, G. Ann. Clin. Microbiol. Antimicrob. 2013, 12, 12. doi:10.1186/1476-0711-12-12

14. Broberg, A.; Bjerketorp, J.; Andersson, P.; Sahlberg, C.; Levenfors, J. Molecules 2017, 22, 1072. doi:10.3390/molecules22071072 
15. Newman, D. J.; Cragg, G. M. J. Nat. Prod. 2016, 79, 629-661. doi:10.1021/acs.jnatprod.5b01055

16. Clofazimine. Monograph for Professionals. https://www.drugs.com/monograph/clofazimine.html (accessed Aug 17, 2021).

17. Dasgupta, D.; Kumar, A.; Mukhopadhyay, B.; Sengupta, T. K. Appl. Microbiol. Biotechnol. 2015, 99, 8653-8665. doi:10.1007/s00253-015-6707-x

18. Kennedy, R. K.; Naik, P. R.; Veena, V.; Lakshmi, B. S.; Lakshmi, P.; Krishna, R.; Sakthivel, N. Chem.-Biol. Interact. 2015, 231, 71-82. doi:10.1016/j.cbi.2015.03.002

19. Fuller, A. T.; Mellows, G.; Woolford, M.; Banks, G. T.; Barrow, K. D.; Chain, E. B. Nature 1971, 234, 416-417. doi:10.1038/234416a0

20. Wuite, J.; Davies, B. I.; Go, M.; Lambers, J.; Jackson, D.; Mellows, G. Lancet 1983, 322, 394. doi:10.1016/s0140-6736(83)90358-6

21. Sutherland, R.; Boon, R. J.; Griffin, K. E.; Masters, P. J.; Slocombe, B.; White, A. R. Antimicrob. Agents Chemother. 1985, 27, 495-498. doi:10.1128/aac.27.4.495

22. Eells, L. D.; Mertz, P. M.; Piovanetti, Y.; Pekoe, G. M.; Eaglstein, W. H. Arch. Dermatol. 1986, 122, 1273-1276. doi:10.1001/archderm.1986.01660230065012

23. Meyer, J.-M.; Hohnadel, D.; Halle, F. J. Gen. Microbiol. 1989, 135, 1479-1487. doi:10.1099/00221287-135-6-1479

24. Cox, C. D.; Graham, R. J. Bacteriol. 1979, 137, 357-364. doi:10.1128/jb.137.1.357-364.1979

25. Cox, C. D.; Rinehart, K. L.; Moore, M. L.; Cook, J. C. Proc. Natl. Acad. Sci. U. S. A. 1981, 78, 4256-4260. doi:10.1073/pnas.78.7.4256

26. Meyer, J.-M. Arch. Microbiol. 2000, 174, 135-142. doi:10.1007/s002030000188

27. Okujo, N.; Saito, M.; Yamamoto, S.; Yoshida, T.; Miyoshi, S.; Shinoda, S. BioMetals 1994, 7, 109-116. doi:10.1007/bf00140480

28. Anthoni, U.; Christophersen, C.; Nielsen, P. H.; Gram, L.; Petersen, B. O. J. Nat. Prod. 1995, 58, 1786-1789. doi:10.1021/np50125a026

29. Zughaier, S. M.; Cornelis, P. Front. Cell. Infect. Microbiol. 2018, 8, 344. doi:10.3389/fcimb.2018.00344

30. Dale, S. E.; Doherty-Kirby, A.; Lajoie, G.; Heinrichs, D. E. Infect. Immun. 2004, 72, 29-37. doi:10.1128/iai.72.1.29-37.2004

31. Górska, A.; Sloderbach, A.; Marszałt, M. P. Trends Pharmacol. Sci. 2014, 35, 442-449. doi:10.1016/j.tips.2014.06.007

32. Möllmann, U.; Heinisch, L.; Bauernfeind, A.; Köhler, T.; Ankel-Fuchs, D. BioMetals 2009, 22, 615-624. doi:10.1007/s10534-009-9219-2

33. Tsubotani, S.; Katayama, N.; Funabashi, Y.; Ono, H.; Harada, S. J. Antibiot. 1993, 46, 287-293. doi:10.7164/antibiotics.46.287

34. Matthijs, S.; Tehrani, K. A.; Laus, G.; Jackson, R. W.; Cooper, R. M.; Cornelis, P. Environ. Microbiol. 2007, 9, 425-434. doi:10.1111/j.1462-2920.2006.01154.x

35. Carmi, R.; Carmeli, S.; Levy, E.; Gough, F. J. J. Nat. Prod. 1994, 57, 1200-1205. doi:10.1021/np50111a002

36. De Meyer, G.; Höfte, M. Phytopathology 1997, 87, 588-593. doi:10.1094/phyto.1997.87.6.588

37. Mercado-Blanco, J.; van der Drift, K. M. G. M.; Olsson, P. E.; Thomas-Oates, J. E.; van Loon, L. C.; Bakker, P. A. H. M. J. Bacteriol. 2001, 183, 1909-1920. doi:10.1128/jb.183.6.1909-1920.2001

38. Sattely, E. S.; Walsh, C. T. J. Am. Chem. Soc. 2008, 130, 12282-12284. doi:10.1021/ja804499r
39. Vodovar, N.; Vallenet, D.; Cruveiller, S.; Rouy, Z.; Barbe, V.; Acosta, C.; Cattolico, L.; Jubin, C.; Lajus, A.; Segurens, B.; Vacherie, B.; Wincker, P.; Weissenbach, J.; Lemaitre, B.; Médigue, C.; Boccard, F. Nat. Biotechnol. 2006, 24, 673-679. doi:10.1038/nbt1212

40. Wuest, W. M.; Sattely, E. S.; Walsh, C. T. J. Am. Chem. Soc. 2009, 131, 5056-5057. doi:10.1021/ja900815w

41. Kanki, M.; Yoda, T.; Tsukamoto, T.; Baba, E. Appl. Environ. Microbiol. 2007, 73, 1467-1473. doi:10.1128/aem.01907-06

42. Watanabe, T.; Taguchi, Y.; Maeyama, K.; Wada, H. Formation of Histamine: Histidine Decarboxylase. Histamine and Histamine Antagonists; Springer Berlin: Berlin, Heidelberg, 1991; Vol. 97, pp 145-163. doi:10.1007/978-3-642-75840-9_13

43. Otto, M.; Wynands, B.; Lenzen, C.; Filbig, M.; Blank, L. M.; Wierckx, N. Front. Bioeng. Biotechnol. 2019, 7, 312. doi:10.3389/fbioe.2019.00312

44. Marshall, C. G.; Hillson, N. J.; Walsh, C. T. Biochemistry 2002, 41, 244-250. doi:10.1021/bi011852u

45. Goodfellow, M.; Fiedler, H.-P. Antonie van Leeuwenhoek 2010, 98 , 119-142. doi:10.1007/s10482-010-9460-2

46. Kupchan, S. M.; Stevens, K. L.; Rohlfing, E. A.; Sickles, B. R.; Sneden, A. T.; Miller, R. W.; Bryan, R. F. J. Org. Chem. 1978, 43, 586-590. doi:10.1021/jo00398a013

\section{License and Terms}

This is an Open Access article under the terms of the Creative Commons Attribution License (https://creativecommons.org/licenses/by/4.0). Please note that the reuse, redistribution and reproduction in particular requires that the author(s) and source are credited and that individual graphics may be subject to special legal provisions.

The license is subject to the Beilstein Journal of Organic Chemistry terms and conditions:

(https://www.beilstein-journals.org/bjoc/terms)

The definitive version of this article is the electronic one which can be found at: https://doi.org/10.3762/bjoc. 17.156 